\title{
SYMBIOTIC EFFECTIVENESS AND ECOLOGICAL CHARACTERIZATION OF INDIGENOUS RHIZOBIUM LOTI POPULATIONS IN URUGUAY1
}

\author{
AMALIA BARAIBAR ${ }^{2}$, LILLIAN FRIONI ${ }^{3}$, MARIA ELENA GUEDES ${ }^{4}$ and HANS LJUNGGREN ${ }^{5}$
}

\begin{abstract}
The objectives of this work were to describe the distribution, density and seasonal variation of the indigenous populations of Rhizobium loti in different Uruguayan soils and to determine the symbiotic effectiveness and stress tolerance factors of different isolates, both with the aim of obtaining selected strains to re-introduce as inoculants in Lotus pastures. $R$. loti was present in ten soils studied and their densities varied from year to year and within each soil. All the isolates nodulated Lotus corniculatus effectively. The nodules in Lotus pedunculatus and Lotus subbiflorus were small, red on the surface and ineffective in nitrogen fixation. The study of 50 isolates from the ten soils showed high variability in their symbiotic efficiency and tolerance to $\mathrm{pH}$. The indigenous population was acid tolerant in culture medium ( $\mathrm{pH} 4.5), 83 \%$ of them could grow at $\mathrm{pH} 4.5$ in 3 days. This work showed that there was a great diversity between the strains of $R$. lot $i$ isolated from Uruguayan soils and supports the importance of selecting among them the most efficient and resistant strains to be included in the inoculants.
\end{abstract}

Index terms: Lotus corniculatus, Lotus pedunculatus, rhizobial $\mathrm{pH}$ tolerance.

\section{EFICIÊNCIA SIMBIÓTICA E CARACTERIZAÇÃO ECOLÓGICA DE UMA POPULAÇÃO NATIVA DE RHIZOBIUM LOTI NO URUGUAI}

\begin{abstract}
RESUMO - Os objetivos deste trabalho foram descrever a distribuição, densidade e variação sazonal de populações nativas de Rhizobium loti em diferentes solos uruguaios, e determinar a eficiência simbiótica e os fatores de tolerância a estresse de diversos isolados, tendo em vista a obtenção de cepas a serem reintroduzidas como inoculantes em pastagens de Lotus. Rhizobium loti estava presente em dez solos estudados, e suas densidades variavam de ano para ano e em cada solo. Todos os isolados nodularam efetivamente o Lotus corniculatus. Os nódulos no Lotus pedunculatus e no Lotus subbiflorus eram pequenos, vermelhos na superfície, e ineficazes na fixação de N. O estudo de 50 isolados dos dez solos mostraram alta variabilidade na sua eficiência simbiótica, e alta tolerância ao $\mathrm{pH}$. A população

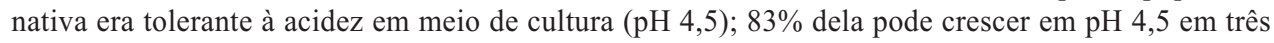
dias. O presente trabalho mostrou que há grande diversidade entre as cepas de $R$. loti isoladas de solos uruguaios, e acentua a importância de se selecionar entre elas as mais eficientes e resistentes, para serem incluídas como inoculantes.
\end{abstract}

Termos para indexação: Lotus corniculatus, Lotus pedunculatus, tolerância do rizóbio ao pH.

\section{INTRODUCTION}

The activity of native Rhizobium population is of great importance, either when a new strain is intro-

${ }^{1}$ Accepted for publication on May 26, 1998.

2 Agronomist, M.Sc., Lage \& Cia., Camino Carrasco 6948, Montevideo, Uruguay.

${ }^{3}$ Chemistry, Dr., Dep. de Ciências Biológicas, Facultad de Agronomia, Montevideo. E-mail: 1frioni@fagro.edu.uy

${ }^{4}$ Agronomist, M. Alvarez 3812/511, Montevideo.

${ }^{5}$ Agronomist, Ph.D., Dep. do Microbiology, Swedish University of Agricultural Sciences, Uppsala, Sweden. duced from an inoculant or as a factor conditioning the persistence of the legume year by year. Inability of the inoculant strains to successfully compete with established Rhizobium populations in soil has been frequently observed (Van Rensburg \& Strijdom, 1985; Triplett \& Sadowsky, 1992). As concluded by Roughley et al. (1976) and Vance \& Graham (1995), the success of an inoculant decreases with increase of native rhizobia population in soil. Furthermore native rhizobia form the highest number of nodules (Rupela \& Sudarshana, 1990).

Lotus corniculatus was introduced in Uruguay many decades ago, especially for production on soils 
of low and medium fertility (Carambula, 1977). In farming Lotus is inoculated with strain U-226. L. pedunculatus and L. subbiflorus are especially adapted to acid soils (Lowther et al., 1987). L. corniculatus and L. tenuis are nodulated by fast growing Rhizobium loti (Jarvis et al., 1982) and L. pedunculatus and L. subbiflorus form nodules with Bradyrhizobium sp. (Lotus). Nevertheless specificity is not yet well defined in the genus Lotus.

Bromfield et al. (1986) and Vance \& Graham (1995) emphasize the importance of understanding the ecology and characteristics of indigenous rhizobia populations as a prerequisite for inoculant establishment and persistence. Characteristics such as: antibiotic resistance (Mueller et al., 1988), fungicide resistance (Curley \& Burton, 1975), low pH tolerance (Munns \& Keyser, 1981; Wood et al., 1988), drought and high temperatures tolerance (Munevar \& Wollum II, 1981; Graham, 1992), bacteriocin production (Schwinghamer \& Brockwell, 1978) are considered in the selection of rhizobial strains with high adaptability in regions with adverse conditions. These properties could explain their saprophytic persistence (Frioni, 1990, 1999).

The objectives of this paper are to describe the distribution, density and seasonal variations of the indigenous populations of Rhizobium loti in different soils; to determine the specifity and level of efficiency of these populations and to obtain selected strains with ecological adaptation in order to introduce them as inoculant into soils with less effective populations.

\section{MATERIAL AND METHODS}

\section{MPN of rhizobia and efficiency of indigenous popula- tions}

Ten soils with different physical and chemical properties were selected in areas with no previous history of legume cultivation (Table 1). The samples were taken from the upper $10 \mathrm{~cm}$ surface soil without plant cover. The MPN of $R$. lot $i$ was determined with seedlings of $L$. corniculatus growing in tubes with Jensen's medium (Vincent, 1970), incubated at $23^{\circ} \mathrm{C}$ and with a photoperiod of 16 hours Besides the soils, three other treatments were included: (C) control without inoculation or fertilizer, (N) with $70 \mathrm{mg} / \mathrm{kg}$ of $\mathrm{N}$ as $\mathrm{KNO}_{3}$ and (I) inoculated with an effi- cient strain, U-226, which is the original B-816 from the Department of Microbiology, Kensington, Australia, and commercially used in inoculant production.

During the spring and fall samples, $R$. loti densities were compared with $R$. leguminosarum bv. trifolii forming nodules in Trifolium repens seedlings.

After 6 weeks the MPN per gram of soil was determinated and after 8 weeks information on the efficiency of the isolates of indigenous population was obtained by determining seedling biomass in tubes with a similar Rhizobium density.

Rhizobia were isolated from the biggest nodules using yeast extract mannitol agar medium (YEM) and maintained in the same medium with $20 \%$ glycerol at $-25^{\circ} \mathrm{C}$ (Somasegaran \& Hoben, 1985).

\section{Symbiotic efficiency}

Tubes with Jensen's medium and seedlings of L. corniculatus, L. pedunculatus and $L$. subbiflorus were inoculated with $10^{3}$ cells /tube with isolates from the soils and strain U-226 in order to define the range of specificity. Data of dry weight of shoots, number and weight of nodules per plant were analyzed by the F test and the averages by the Tukey test (Snedecor \& Cochran, 1977). The relative efficiency index (Brockwell et al., 1966) measure the accumulation of $\mathrm{N}$ fixed in relation to the controls, and defined as REI $=(\mathrm{T}-\mathrm{C} / \mathrm{N}-\mathrm{C}) \mathrm{X} 100$, where $\mathrm{T}, \mathrm{C}$ and $\mathrm{N}=$ dry weight of shoots in each treatment, in control and in nitrogen treatment, respectively.

\section{Tolerance to low $\mathrm{pH}$}

The Wood \& Cooper (1985) technique using liquid medium and recording the days until the appearance of net turbidity was employed. The work was done in the range of $\mathrm{pH} 3.5$ to 6.8 .

\section{Bacteriocin production}

The production of these intraspecific inhibitor substances was evaluated by measuring the inhibition zones (cm) after 7 days of growth in a double layer system. Each strain was sown with a multiple replicator in solid YEM medium and test strain was inoculated in the botton layer and treated with choloform after growth (Pugsley \& Oudeg, 1987).

\section{RESULTS AND DISCUSSION}

\section{Indigenous population of Rhizobium loti}

All the ten soils chosen to be representative of the Uruguayan soils (Table 1) contained R. loti. They 
TABLE 1. Characteristics of soils ${ }^{1}$.

\begin{tabular}{lccccccr}
\hline $\begin{array}{l}\text { Soils and } \\
\text { classification }\end{array}$ & $\begin{array}{c}\mathrm{pH}\left(\mathrm{H}_{2} \mathrm{O}\right) \\
(1 / 2.5)\end{array}$ & $\begin{array}{c}\mathrm{pH}(\mathrm{KCl} 1 \mathrm{~N}) \\
(1 / 2.5)\end{array}$ & $\mathrm{OM}$ & $\mathrm{OrgN}$ & $\mathrm{P}$ & $\mathrm{Al}^{3+}$ & $\mathrm{Clay}^{3}$ \\
\hline $\begin{array}{l}\text { Algorta (A) } \\
\text { Distric Argisol }\end{array}$ & 5.7 & 4.8 & 1.78 & 0.12 & 2.2 & 0 & 9.6 \\
$\begin{array}{l}\text { Estación Experim. del Este (E) } \\
\text { Distric Planosol }\end{array}$ & 5.9 & 4.3 & 1.98 & 0.11 & 1.2 & 0 & 19.0 \\
$\begin{array}{l}\text { Glencoe (G) } \\
\text { Haplic Vertisol }\end{array}$ & 5.9 & 4.8 & 7.91 & 0.33 & 2.7 & 0 & 42.7 \\
$\begin{array}{l}\text { Bañado de Medina (M1) } \\
\text { Ruptic Vertisol }\end{array}$ & 5.2 & 4.2 & 6.27 & 0.37 & 9.2 & 0 & 50.3 \\
$\begin{array}{l}\text { Bañado de Medina (M2) } \\
\text { Sub-EutricBrunosol }\end{array}$ & 5.5 & 4.4 & 4.74 & 0.37 & 6.0 & 0 & 28.1 \\
$\begin{array}{l}\text { Estación Experim. SUL (S) } \\
\text { Distric Brunosol }\end{array}$ & 5.3 & 4.1 & 3.16 & 0.20 & 1.2 & 0.40 & 23.1 \\
$\begin{array}{l}\text { Seroterápico (Se) } \\
\text { Ruptic Vertisol }\end{array}$ & 6.1 & 5.1 & 8.07 & 0.40 & 2.9 & 0 & 36.1 \\
$\begin{array}{l}\text { Suarez (Su) } \\
\text { Sub Eutric Brunosol }\end{array}$ & 5.7 & 4.4 & 4.33 & 0.20 & 0.8 & 0 & 26.1 \\
$\begin{array}{l}\text { Tacuarembó (T) } \\
\text { Ocric Luvisol }\end{array}$ & 5.2 & 4.2 & 2.68 & 0.14 & 5.4 & 0.46 & 10.1 \\
$\begin{array}{l}\text { Young (Y) } \\
\text { Eutric Brunosol }\end{array}$ & 5.9 & 4.9 & 5.77 & 0.34 & 5.0 & 0 & 36.4 \\
\hline
\end{tabular}

${ }^{1}$ Methods: OM (\%) - Walker \& Black; N (\%) - Kjeldahal; P (mg/kg) - Olsen; Al (mg/kg) - Black; Clay (\%) - Bouyoucus.

nodulated L. corniculatus effectively, but in assays with L. pedunculatus and L. subbiflorus, the nodules formed were small, ineffective and red at the exterior as described by Pankhurst et al. (1987) and seems to be related to the flavolan content of nodulated roots of several Lotus species, proved to be toxic to many $R$. loti strains.

Table 2 shows the density of $R$. loti and $R$. leguminosarum bv. trifolii using the MPN technique. In general a higher $R$. loti population in relation to R. leguminosarum bv. trifolii was noticed. In the winter samples $R$. lot $i$ was not detected except in $\mathrm{T}$ soil $(\log =2.23)$. The average for the autumn season was $3.08 \log$ units, with values from 1.57 to 5.35 . The average for the spring-summer samples was $3.3 \log$ units. The eutric Brunosol Y showed the highest Rhizobium densities related to the nutritional levels and textural properties.
TABLE 2. Rhizobium loti and R. leguminosarum bv. trifolii in soils $\left(\log _{10} \mathrm{~N}^{\%} / \mathrm{g}\right.$ dry soil) ${ }^{1}$.

\begin{tabular}{|c|c|c|c|c|c|}
\hline \multirow[t]{2}{*}{ Soils $^{2}$} & \multirow{2}{*}{$\begin{array}{l}\text { R. loti } \\
\text { Winter }\end{array}$} & \multicolumn{2}{|c|}{ R. loti } & \multicolumn{2}{|c|}{ R. leguminosarum } \\
\hline & & Spring & Autumn & Spring & Autumn \\
\hline A & 0 & 0 & 3.51 & 2.76 & 2.46 \\
\hline $\mathrm{E}$ & 0 & 0 & 2.01 & ND & 0 \\
\hline G & 0 & 0 & 2.76 & 2.33 & 2.92 \\
\hline M1 & 0 & 0 & 3.51 & 0 & 3.92 \\
\hline M2 & ND & 0 & 1.57 & 0 & ND \\
\hline $\mathrm{S}$ & 0 & 2.76 & 3.28 & 0 & 1.48 \\
\hline $\mathrm{Se}$ & ND & 3.26 & 2.33 & 0 & 0 \\
\hline $\mathrm{Su}$ & 0 & 2.49 & 3.54 & 0 & ND \\
\hline $\mathrm{T}$ & 2.33 & 3.76 & 2.98 & 2.76 & 1.48 \\
\hline $\mathrm{Y}$ & 0 & 4.23 & 5.35 & 4.23 & 4.46 \\
\hline
\end{tabular}


Only for the R. leguminosarum bv. trifolii there was a positive correlation between their densities and organic $\mathrm{N}(\%)(\mathrm{r}=0,65)$ and clay content of soils $(\mathrm{r}=0,69)$. The $R$. loti densities did not correlate with soil parameters presented in Table 1. However, Woomer et al. (1988) related total rhizobial populations to many soil parameters as: temperature, soil $\mathrm{pH}$ and phosphorus content.

The result of the symbiotic efficiency in the indigenous population of $R$. lot $i$ in the ten soils, in the treatment with $\mathrm{U}-226$ and $\mathrm{N}$ supply are presented in Table 3. The shoot dry weight was lower for all of the soils populations compared to the $\mathrm{N}$ or $\mathrm{U}-226$ treatment. Only native Rhizobium population of soil S neither differ statistically from U-226 nor from the nitrogen treatment. Although the soil Y presented the highest rhizobia density related to their nutritional levels and textural properties it was not the most efficient (Table 3). The REI of the indigenous populations of $R$. loti, except soil S, was lower than $50 \%$.

TABLE 3. Symbiotic efficiency of indigenous population of $R$. loti.

\begin{tabular}{lccc}
\hline Soils $^{1}$ & $\begin{array}{c}\text { Dry weight of } \\
\text { shoots (mg/plant) }\end{array}$ & REI $^{2}$ & $\begin{array}{c}\text { No nodules/ }^{\text {plant }} \\
\text { pla }^{3}\end{array}$ \\
\hline $\mathrm{A}$ & $8.83 \mathrm{~b}$ & 34.10 & $10.5 \mathrm{bc}$ \\
$\mathrm{E}$ & $5.80 \mathrm{c}$ & 16.88 & $5.8 \mathrm{e}$ \\
$\mathrm{G}$ & $10.45 \mathrm{abc}$ & 48.54 & $8.7 \mathrm{~d}$ \\
$\mathrm{M} 1$ & $9.91 \mathrm{abc}$ & 44.86 & $8.9 \mathrm{~d}$ \\
$\mathrm{M} 2$ & $6.08 \mathrm{c}$ & 18.79 & $5.1 \mathrm{e}$ \\
$\mathrm{S}$ & $14.95 \mathrm{ab}$ & 79.17 & $13.7 \mathrm{a}$ \\
$\mathrm{Se}$ & $7.91 \mathrm{bc}$ & 31.24 & $6.5 \mathrm{e}$ \\
$\mathrm{Su}$ & $8.60 \mathrm{bc}$ & 35.94 & $9.1 \mathrm{~cd}$ \\
$\mathrm{~T}$ & $8.86 \mathrm{bc}$ & 37.71 & $10.9 \mathrm{bc}$ \\
$\mathrm{Y}$ & $9.76 \mathrm{bc}$ & 43.84 & $10.1 \mathrm{~cd}$ \\
$\mathrm{U} 226^{4}$ & $17.79 \mathrm{a}$ & 82.50 & $12.3 \mathrm{ab}$ \\
$\mathrm{N}^{5}$ & $20.95 \mathrm{a}$ & & \\
\hline $\mathrm{F}^{6}$ & ++ & & + \\
\hline $\mathrm{CV}(\%)$ & 20.53 & & 10.3 \\
\hline
\end{tabular}

${ }^{1}$ See Table 1.

${ }^{2}$ Relative efficiency index.

${ }^{3}$ Data normalized.

${ }^{4}$ Commercial strain

${ }^{5} \mathrm{~N}$ treatment.

${ }^{6}+$ and $++=$ significant differences at $5 \%$ and $1 \%$ respectively

\section{Rhizobium loti isolates}

In relation to REI of the 50 isolates of $R$. loti, $6 \%$ was between $100-119 \%$ and another $6 \%$ were located in the $0-40 \%$ range (Fig. 1). The mean of the REI of the isolates from each soil compared with the efficiency determined from the indigenous populations of the soils was shown in Fig. 2.

Isolates from five soils showed REI superior to $70 \%$ and the mean of the REI of the other five soils was $60 \%$. REI values of the isolates in relation to REI of the indigenous population is visibly higher in all cases, except in the soils G and S. In two cases the REI of isolates was up to four times higher than that of the respective soil Rhizobium population.

A great variation in the REI of the isolates of the same soil was observed. REI of strains from the

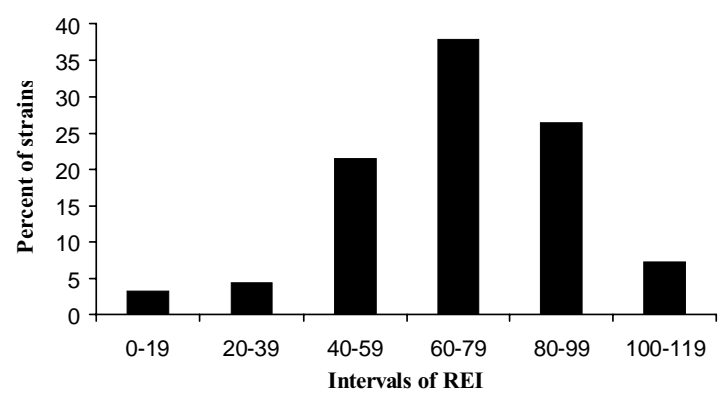

FIG. 1. Symbiotic efficiency of $\mathbf{5 0}$ isolates of $\boldsymbol{R}$. loti as intervals of relative efficiency index (REI).

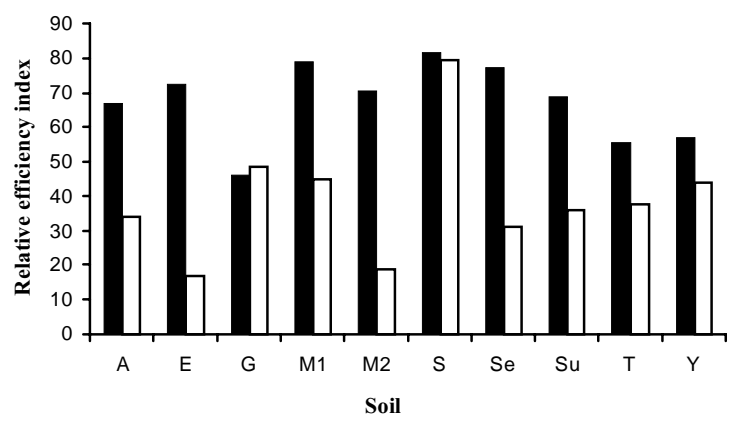

FIG. 2. Symbiotic efficiency in each soil expresed as relative efficiency index (REI) in isolates of strains ( $\square$ ) and indigenous populations ( $\square$ ) of $R$. loti. 
Brunosol varied from less than $40 \%$ to $90 \%$. Soil M1 is characterised by a high level of organic matter and phosphorus (Table 1), with a high indigenous population of $R$. loti $(\log =3.51)$ (Table 2). The sandy soil $\mathrm{T}$ with low levels of organic matter and $\mathrm{pH}$ showed a great dispersion in REI of their isolates (15 to $93 \%$ ).

The diversity in symbiotic performance of native population of $R$. loti emphasised the importance of selection of an inoculant strain for the successful establishment in soils (Bonish \& Mac Farlane, 1987).

\section{Nodulation}

In general the levels of nodulation with the isolates were of the same order as the U-226 (Table 3). The correlation indexes between nodulation and shoots dry weight were: nodules dry weight/nodule number $(\mathrm{r}=0.48)$, shoots dry weigth/nodule number $(r=0.32)$ and shoot dry weight/nodule dry weight $(\mathrm{r}=0.31)$.

\section{Tolerance to low pH}

All 50 isolates of $R$. loti grew at $\mathrm{pH} 4.5,5.5$ and 6.8 and most of them during the three days of incubation (Fig. 3). At pH 3.5, $44 \%$ of the strains grew and $28 \%$ of them did it in five days of incubation. At $\mathrm{pH} 4.5,83 \%$ of the isolates grew in three days, at $5.5,44 \%$, and at $\mathrm{pH} 6.8,33 \%$. The U-226 strain grew at $\mathrm{pH} 4.5$ and 5.5 in five days and in $\mathrm{pH} 6.8$ in seven days.

Jarvis et al. (1982) stated a minimum $\mathrm{pH}$ for this species of 4.0. Cooper (1982) found that none of 20 strains of Bradyrhizobium sp. (Lotus) developed at $\mathrm{pH}$ 4.6, while three out of seven strains of $R$. loti did grow at this $\mathrm{pH}$. We found a growth optimum of the population to be near $\mathrm{pH} 4.5$ (83\% grew in three days). These seem to be acidophilic strains. Changes in metabolic activity as a consequence of external $\mathrm{pH}$ could explain the growth in acid medium. Ayanaba et al. (1983) noted significant ammonia production in acid-tolerant cowpea rhizobia in medium of $\mathrm{pH} 4.5$.

In more neutral $\mathrm{pH}, 73 \%$ of the strains needed more than five days for giving a net turbidity. The neutral $\mathrm{pH}$ revealed different behaviour between

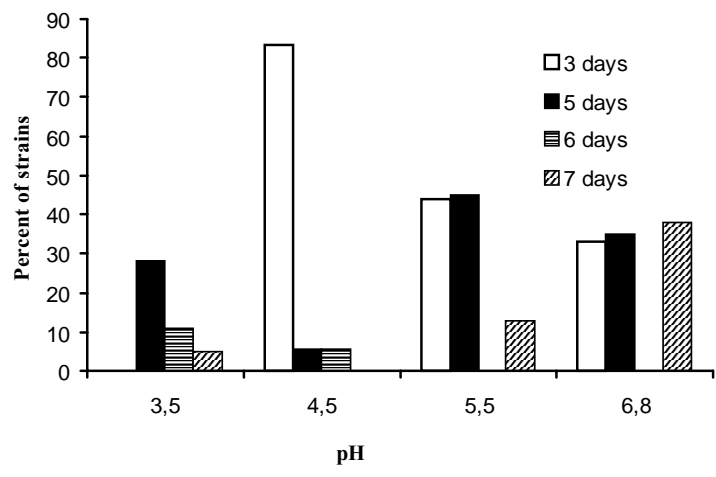

FIG. 3. Growth of $R$. loti at diferent pH.

R. loti strains. Valdes \& Martinez-Bravo (1986) found that $28 \%$ of $R$. loti strains isolated from Leucaena were acidophilic ( $\mathrm{pH}$ 5.0). Laboratory studies have been effective in identifying sensitive strains to the environmental factors but field studies are important to verify the results (Blanchar \& Lipton, 1986). Vargas \& Graham (1989) found good correlations between growth in acidic medium and nodulation capacity in acidic soils.

\section{Bacteriocines}

Only $4 \%$ of the tested strains presented antagonistic activity: G4 against U226 with bacteriocin inhibition zone diameter of $1.5 \mathrm{~cm}$ and A12 against E7, $2.5 \mathrm{~cm}$ inhibition zone. The bacteriocin producing strains, could increase nitrogen fixation by means of the suppression of competition for nodulation sites in the native population (Hodgson et al., 1985).

\section{CONCLUSIONS}

1. The ten soils analyzed present $R$. loti populations with logarithmic densities ranged from 1.48 to 5.35 per gram. In general, a higher $R$. loti population in relation to $R$. leguminosarum bv. trifolii was found in the analized soils.

2. The symbiotic efficiency of 50 isolates show a great diversity in Lotus corniculatus and $22 \%$ of the strains accumulate significantly more dry matter than U-226 used as a inoculant.

3. Eighty three percent of the isolates can grow at $\mathrm{pH} 4.5$ in three days in liquid medium and sup- 
ported lower $\mathrm{pH}$ in relation to U-226 strain used in the inoculants production.

4 . There is a great diversity between the isolates of $R$. loti from Uruguayan soils.

\section{ACKNOWLEDGEMENTS}

This work was supported by grants from SAREC (Swedish Agency for Research Cooperation), Sweden and from the Research Commission of the University of the Republic.

\section{REFERENCES}

AYANABA, A.; ASANUMA, S.; MUNNS, D.N. An agar plate method for rapid screening of Rhizobium for tolerance to acid-aluminium stress. Soil Science Society of American Journal, v.17, p.254-258, 1983.

BLANCHAR, R.W.; LIPTON, D.S. The pE and $\mathrm{pH}$ in alfalfa seedling rhizosphere. Agronomy Journal, v.78, p.216-218, 1986.

BONISH, P.M.; MAC FARLANE, M.J. Nodulation of introduced white clover by naturalised soil clover rhizobia: symbiotic effectiveness and host-strain compatibility. New Zealand Journal of Agricultural Research, v.30, p.273-280, 1987.

BROCKWELL, J.; HELY, F.W.; NEAL-SMITH, C.A. Some symbiotic characteristics of rhizobia responsible for spontaneous, effective field nodulation of Lotus hispidus. Australian Journal of Experimental Agricultural and Animal Husbandry, v.6, p.365-370, 1966.

BROMFIELD, E.S.P.; SINHA, I.B.; WOLYNETZ, M.S Influence of location, host cultivar and inoculation on the composition of naturalized populations of Rhizobium meliloti in Medicago sativa nodules. Applied and Environmental Microbiology, v.51, p.1077-1084, 1986.

CARAMBULA, M. Producción y manejo de pasturas sembradas. Montevideo: Hemisferio Sur, 1977. $464 \mathrm{p}$.

COOPER, J.E. Acidic production, acid tolerance and growth rate of lotus rhizobia in laboratory media. Soil Biology and Biochemistry, v.14, p.127-131, 1982.

Pesq. agropec. bras., Brasília, v.34, n.6, p.1011-1017, jun. 1999
CURLEY, R.L.; BURTON, J.C. Compatibility of Rhizobium japonicum with chemical seed protectans. Agronomy Journal, v.67, p.807-808, 1975.

FRIONI, L. Ecología microbiana del suelo. Montevideo: Depto. de Publicaciones de la Universidad de la República, 1990, p.203-258.

FRIONI, L. Procesos microbianos. Rio Cuarto: Universidad Nacional de Rio Cuarto, Argentina, 1999. T.1, 282p., T.2, 286p.

GRAHAM, P. Stress tolerance in Rhizobium and Bradyrhizobium and nodulation under adverse soil conditions. Canadian Journal of Microbiology, v.38, p.475-484, 1992.

HODGSON, A.L.M.; ROBERTS, W.P.; WAID, J.S. Regulated nodulation of Trifolium subterram inoculated with bacteriocin-producing strains of Rhizobium trifolii. Soil Biology and Biochemistry, v.17, p.475-478, 1985.

JARVIS, B.D.W.; PANKHURST, C.E.; PATEL, J.J. Rhizobium loti, a new specie of root nodule bacteria. International Journal of Systematic Bacteriology, v.32, p.378-380, 1982.

LOWTHER, W.L.; HAY, R.J.M.; RYAN, D.L. Effect of strain of rhizobia, lime and phosphorus on dry matter yield of three lotus species in differing environments in Otago and Southland. New Zealand Journal of Experimental Agriculture, v.15, p.135-142, 1987.

MUELLER, J.G.; SKIPPER, H.D.; SHIPE, E.R.; GRIMES, L.W.; WAGNER, S.C. Intrinsic antibiotic resistance in Bradyrhizobium japonicum. Soil Biology and Biochemistry, v.20, p.879-882, 1988.

MUNEVAR, F.; WOLLUM II, A.G. Growth of Rhizobium japonicum strains in temperature above $27^{\circ} \mathrm{C}$. Applied and Environmental Microbiology, v.42, p.272-276, 1981.

MUNNS, D.N.; KEYSER, H.H. Responses of Rhizobium strains to acid and aluminium stress. Soil Biology and Biochemistry, v.13, p.115-118, 1981.

PANKHURST, C.E.; HOPCROFT, D.H.; JONES, W.J. Comparative morphology and flavolan content of Rhizobium loti induced effective and ineffective root nodules on Lotus species, Leucaena leucocephala, Carmichaelia flagelliformis, Ornithopus sativus and Clianthus puniceus. Canadian Journal of Botany, v.65, p.2676-2685, 1987. 
PUGSLEY, A.P.; OUDEG, B. Methods for studying colicins and their plasmid. In: HARDY, K.G. (Ed.) Plasmids: A practical approach. Oxford: IRL Press, 1987. p.101-108.

ROUGHLEY, R.J.; BLOWES, W.M.; HERRIDGE, D.F. Nodulation of Trifolium subterraneum by introduced rhizobia in competition with naturalized strains. Soil Biology and Biochemistry, v.8, p.403-407, 1976.

RUPELA, O.P.; SUDARSHANA, M.R. Displacement of native rhizobia nodulating chick pea (Cicer arietinum L.) by an inoculant strain through soil solarization. Biology and Fertility Soils, v.10, p.207-212, 1990.

SCHWINGHAMER, E.A.; BROCKWELL, J. Competitive advantage of bacteriocin and phage producing strains of Rhizobium trifolii in mixed culture. Soil Biology and Biochemistry, v.10, p.383-387, 1978.

SNEDECOR, W.G.; COCHRAN, G.W. Métodos Estadísticos. Méjico: Continental, 1977. 703p.

SOMASEGARAN, P.; HOBEN, H.J. Methods in legume - Rhizobium technology. Hawaii: MIRCEN/ NifTAL, 1985. 367p.

TRIPLETT, E.W.; SADOWSKY, M.J. Genetics of competition for nodulation of legume. Annual Review of Microbiology, v.46, p.399-428, 1992.

VALDES, M.; MARTINEZ-BRAVO, E.M. Características de cultivo y bioquímicas de Rhizobium loti. Revista Latinoamericana de Microbiología, v.28, p.89-94, 1986.
VAN RENSBURG, H.J.; STRIJDOM, B.W. Effectiveness of Rhizobium strains used in inoculants after their introduction into soil. Applied and Environmental Microbiology, v.49, p.127-131, 1985.

VANCE, C.P.; GRAHAM, P.H. Nitrogen fixation in agriculture: application and perspectives. In: TIKHONOVICH, I.A.; PROVOROV, N.A.; ROMANOV, V.I.; NEWTON, W.E. (Eds.). Nitrogen fixation: Fundamentals and applications. Netherlands: Kluver Academic Publishers, 1995. p.77-86.

VARGAS, A.A.T.; GRAHAM, P.H. Cultivar and pH effects on competition for nodule sites between isolates of Rhizobium in beans. Plant and Soil, v.117, p.195-200, 1989.

VINCENT, J.M. A manual for the practical study of root nodule bacteria. Oxford: Blackwell, 1970. $164 \mathrm{p}$.

WOOD, M.; COOPER, J.E. Screening clover and Lotus rhizobia for tolerance of acidity and aluminium. Soil Biology and Biochemistry, v.17, p.493-497, 1985.

WOOD, M.; COOPER, J.E.; JOURSON, A.J.B. Response of Lotus rhizobia acidity and aluminium in liquid culture and in soil. Plant and Soil, v.107, p.227-232, 1988.

WOOMER, P.; SINGLETON, P.W.; BOHLOOL, B.B. Ecological indicators of native rhizobia in tropical soils. Applied and Environmental Microbiology, v.54, p.1112-1116, 1988. 